University for Business and Technology in Kosovo

UBT Knowledge Center

Nov 8th, 2:15 PM - 2:30 PM

\title{
European debt crisis -the follow up of the global financial crisis or specific European phenomenon?
}

\author{
Violeta Madzova \\ University Goce Delcev, violeta.madzova@ugd.edu.mk \\ Nehat Ramadini \\ University for Business and Technology, nehat.ramadani@ubt-uni.net
}

Follow this and additional works at: https://knowledgecenter.ubt-uni.net/conference

Part of the Business Commons

\section{Recommended Citation}

Madzova, Violeta and Ramadini, Nehat, "European debt crisis -the follow up of the global financial crisis or specific European phenomenon?" (2014). UBT International Conference. 43.

https://knowledgecenter.ubt-uni.net/conference/2014/all-events/43

This Event is brought to you for free and open access by the Publication and Journals at UBT Knowledge Center. It has been accepted for inclusion in UBT International Conference by an authorized administrator of UBT Knowledge Center. For more information, please contact knowledge.center@ubt-uni.net. 


\title{
European debt crisis -the follow up of the global financial crisis or specific European phenomenon?
}

\author{
${ }^{1}$ Violeta Madzova, ${ }^{2}$ Nehat Ramadani \\ ${ }^{1}$ University Goce Delcev -Faculty of Economics -Stip \\ University for Bussiness and Technology -Prishtina, Kosova \\ violeta.madzova@ugd.edu.mk, nehat.ramadani@ubt-uni.net
}

\begin{abstract}
While the recent financial crisis was global by its nature, it made a different impact on financial stability and economic development in different regions of the world

European Union with its unique institutions and mechanisms, experienced very specific environment in the financial and post financial crisis period, trying to solve the problems with extreme measures and borrowing increasing, which additionally worsted the situation.

Many economist think that the European debt crisis is just specific follow up of the global financial crisis from 2007, however, many indicators implies that the European debt crisis has been developed and is so severe due to specific factors immanent only for Europe, European financial markets and way of EU institutions functioning .

This paper's aim is to analyze the broad range of factors which contributes the European debt crisis to be so unique and so severe as well as to vary when different Eurozone countries caught by the crisis are considered.
\end{abstract}

Key words: European debt crisis, sovereign debt, state bonds, EMU mechanisms.

\section{Introduction}

In the last few years the EU member states have been facing two interrelated crises: a banking crisis, stemming from losses in capital markets as well as from property markets in some EU countries; and a sovereign debt crisis driven by the effects of the recession on the budget and on the re-assessment of sovereign risk by financial operators, the transfers necessary to support the financial sector, and in some cases very poor fiscal management over a number of years. The reasons and forms of appearance of sovereign debt crisis vary from country to country. Namely, in several countries, private debts incurred by individual banks or other financial institutions during the mortgage banking crisis of 2007, resulted with an increase of public debt, due to financial injections that states gave their banking systems, or financial measures that the governments undertook in response to slowdown of economic growth in the period after the mortgage banking crisis. In other countries, high public sector wage and pension commitments were connected to the debt increase. Basically, the existence of the Eurozone as a Monetary Union contribute to fueling the crisis and reduce the ability of European leaders to respond uniformly to the same. In fact, much of that debt belongs to European banks in response to the governments to maintain solvency of their banks, but many effects on the budget of the states intervened. However, there have been occasions when, despite the intervention of the state to maintain the solvency of the banking system, some banks still were fragile without looking to their feet, without any state aid or assistance of international financial institutions. The crisis not only cause the so-called adverse economic effect in the most affected countries by the debt crisis, but also had a negative political effect, resulting with a change of political power in eight out of seventeen Eurozone countries.

\section{European sovereign debt crisis -how did it happen?}

The European sovereign debt crisis is called the current period of financial crisis in the euro area when several European countries faced the collapse of financial institutions, high government debt and rapidly rising bond yield spreads in government securities. This has caused difficulties for those countries to repay or re-finance their government debt without the assistance of third parties which led to a crisis of confidence for European businesses and economies. 
The European sovereign debt crisis started in 2008, with the collapse of Iceland's banking system, and spread primarily to Greece, Ireland and Portugal during 2009. From late 2009, fears of a sovereign debt crisis developed among investors, as a result of the rising private and government debt levels around the world, together with a wave of downgrading of government debt in some European states. All this, has made investors more cautious and additionally slowed down economic growth in these countries.

At first glance it looks impossible for European Union, known by its strict rules and procedures, to allow such anarchy in financial and economic sector. In fact, when the monetary union was formed, the countries involved agreed to fiscal requirements called the Maastricht accords, also known as the convergence criteria. The agreement required that government debt not exceed 60 percent of the country's gross domestic product, or GDP, and that the budget deficit amount to no more than 3 percent of GDP. However, these rules, were broken almost immediately, by many European countries, as well as the EU leading ones, such as France and Germany, and no controlling mechanisms were establish at that time, so it seemed that no one pay attention to it. In fact, monetary unification brought many unexpected consequences upon certain economies within Eurozone, losing their competitiveness, due to the fact that they could not devaluate their own currencies any longer as they used to do before introduction euro ${ }^{28}$.However, in 2003, quite aware of the possible negative consequences of budget deficit and high government debt, Germany has decided to undertake measures by introducing a series of labor market reforms, known as the Hartz reforms, which were part of a broader reformation known as Agenda 2010. The reforms required cuts of the welfare benefits and slow increase of workers' salaries, which resulted in very competitive labor costs, and competitive national goods and services at the international market. While Germany remodeled its economy, other countries enjoyed the benefits of living under one currency and increasing the labor inputs and compensate the budget deficits with borrowings at financial markets with low interest rate. So, comparing the growth rate of input costs, labor costs in Germany over the last 10 years, with the labor cost increases in southern Europe, the fact is that the labor costs in Germany barely increased maybe 10 percent over 10 years, while some of Europe had labor cost increases to the tune of about 120\%. (Figure 1).

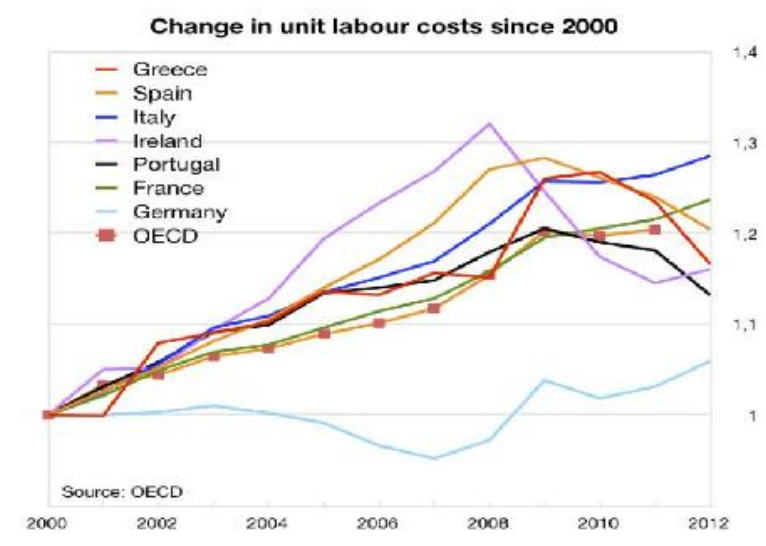

Figure 1 Change in unit labor costs in EU countries in \% (2002-2012)

Source: $O E C D$

The comfortable position of the countries from Eurozone, came from the ECB banking regulation that the Eurobonds issued by the government of any EMU country have zero-risk weighting and is rated with highest credit rates. Thus, bonds issued in foreign currencies by governments with a certain credit rating or above were viewed as risk-free. Sovereign debt issued in the bank's own currency wasn't subject to a credit rating threshold. So European banks, as well as all other banks in the world could buy

\footnotetext{
${ }^{28}$ Sheyla "What caused Europe's debt crisis, anyway?" http://ca.finance.yahoo.com/news/caused-europes-debt-crisis-anyway-070127716.html
} 
lots of bonds from already over debt EU countries (such as Greece for example ) for a little extra yield and count them as risk-free. Banking regulations also allow financial institutions to count risk-free investments, such as sovereign debt, as part of their required liquidity, or available cash.In 2009 when the full extent of the problems in Greece came to light, banks all over Europe that had bought piles of Greek debt suddenly had a lot less liquidity and began having trouble finding credit. Thus, high levels of debt, low levels of tax compliance and government largesse combined to bring an end to the party in Greece. By late 2009, Greek debt had ballooned to $113 \%$ percent of GDP. Once the credit rating agencies began downgrading Greece, their borrowing costs soared and the Greeks quickly found themselves unable to pay the interest rate on the debt.When the credit rating agencies have started reducing Greece's credit rating, borrowing costs were increasing so quickly that Greece was unable to pay the required interest rates. Of course the financial assistance from the third parties was needed, as the Government could do by itself. Germany, as the strongest economic country in the Eurozone, bore the greatest brunt of such financial assistance, to the great disappointment of German taxpayers. In fact, for all countries which needed financial assistance (as in the case of Greece), three official lenders - the European Commission, European Central Bank and the International Monetary Fund ( so called Troika) had budgetary requirements that should be met before they can take any credit. Their requirements are known as austerity measures and required cuts in government spending and entitlements. All these, additionally worsened the economic situation in the affected countries and caused social uncertainty and recession in their economies.

\section{Causes for occurrence and spreading of European sovereign debt crisis}

Many analysts think that the European sovereign debt crisis is simple follow up of the last global financial crisis, but, of course, it is also considered as specific phenomenon influenced by a number of factors which are unique for the countries of the Eurozone. Although there are many factors and preconditions which are pointed out as crucial causes for the Europeand debt crisis, it can be concluded that it resulted from a combination of complex factors, such as:

- Global banking crisis (2007-2009);

- Financial globalization;

- Relaxation of credit terms;

- International trade imbalances;

- Practices to rescuing troubled banks or financial funds by the Governments of certain EU economies and increasing public debt on that basis;

- Structural problems of the Eurozone (existance of monetary union without fiscal union);

- Inflexibility of monetary policy of the Eurozone and the loss of confidence in the mechanisms of the Eurozone ${ }^{29}$.

\subsection{The global banking crisis ( 2007-2009)}

In the period 2000-2007 much of the discretionary income of corporations and banks, as well as individual savings were invested in fixed income securities, increasing their value from about $\$ 3,6$ trillion in 2000 to $\$ 70$ trillion in 2007. This expanded pool of funds in form of savings from highgrowth developing nations entered global capital markets. Thus, it seemed that the investors who were seeking for higher yields, have found a suitable alternative globally.

The temptation offered by such readily available savings overwhelmed the policy and regulatory control mechanisms in countries, as lenders and borrowers put these savings to use, generating bubbles across the globe. While these bubbles have burst, causing asset prices (e.g., housing and commercial property) to decline, the liabilities owed to global investors remain at full price, generating issue of the solvency of the governments and their banking systems.

\footnotetext{
${ }^{29}$ Lewis, Michael (2011). "Boomerang - Travels in the New Third World". Norton. ISBN 978-0-
} 393-08181-7. 
The way that each European country involved in this crisis borrowed and invested the money varies from case to case. For example, Ireland's banks lent the money to property developers, generating a massive property bubble. When the bubble burst, Ireland's government and taxpayers assumed private debts. In Greece, the government increased its commitments to public workers in the form of extremely generous wage and pension benefits, with the former doubling in real terms over 10 years. Iceland's banking system grew enormously, creating debts to global investors in amount that exceeds GDP several times.(Figure 2)

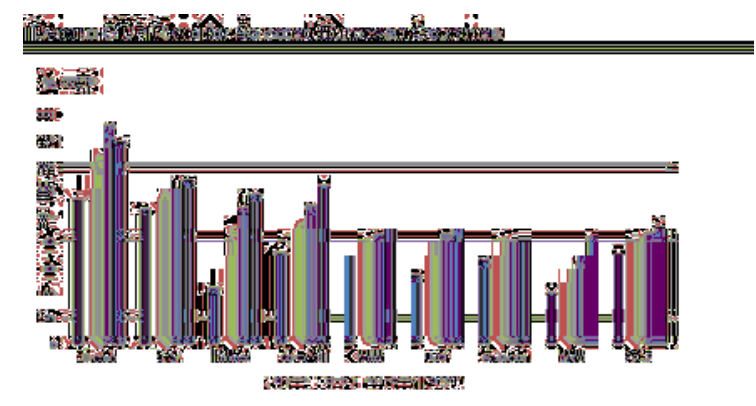

Figure 2: Debt to GDP ratio for selected EU countries

\section{Source :ECB}

\subsection{Financial globalization}

The interconnection in the global financial system caused the situation of so called financial contingation. It means that if one country defaults on its sovereign debt or enters into recession putting some of the external private debt at risk, it would cause the losses of the banking systems of creditors. For example, in October 2011, Italian borrowers owed French banks $\$ 366$ billion. In case Italy be unable to finance itself, the French banking system and economy could come under significant pressure, which in turn would affect France's creditors ${ }^{30}$.

Another moment which derives from financial globalization, is the concept of debt protection. Namely, financial institutions made contracts on credit default swaps (CDS), to protect the defaults of their debt instruments (including government issued bonds). However, since the hedging of the same sequrity which is subject on re-investements at the international financial markets, can be done with multiple CDSs, the real exposure of the creditors to CDS remained uncertain, thus the credit rating of the main instruments didn't correspond to their real credit risk exposure ${ }^{31}$.

\subsection{Relaxed credit policy and increased housholds and Governments debt levels}

According to the Maastricht Treaty, signed in 1992, members of the European Union pledged to limit their deficit spending at the level of 3\% to GDP and public debt at the level of $60 \%$ to GDP. However, a number of EU member states, didn't obey these rules, ignoring internationally agreed standards. This allowed the Governments to mask their deficit and debt levels through a combination of techniques, including inconsistent accounting, off-balance-sheet transactions, as well as the use of complex currency and credit derivatives. The complex structures were designed by prominent the investment banks, who received substantial fees in return for their services.

\footnotetext{
30“'It's all connected: Spectator's duide to the World crises", http://www.nytimes.com

31" The euro deal -No big bazooka"-The Economist , 29.10.2011,

http://www.economist.com/node/21534851
} 
Also, the adoption of the euro has led many Eurozone countries with different creditworthiness to obtain similar and very low interest rates on their loans or bonds issued during the years before the crisis, which Michael Lewis called "a sort of implicit Germany guarantee ". As a result, creditors in countries with originaly weak currencies (and higher interest rates), suddenly enjoyed favorable conditions for lending, which encouraged private and government appetite for borrowing and led to an economic boom .In some countries, low interest rates, led to the creation of so-called housing bubble, which burst at the height of the financial crisis. ${ }^{32}$

\subsection{Trade imbalances}

Analysts and the Financial Times journalist Martin Wolf argues that the root of the crisis was the growing trade imbalances of EU countries. He notes that before the crisis period, Germany has a much more favorable ratio of public debt and fiscal deficit to GDP, than the most affected eurozone members. In the same period, these countries (Portugal, Ireland, Italy and Spain) had far worse balance of payments positions .So, while German trade surpluses increased as a percentage of GDP after 1999, the deficits of Italy, France and Spain all worsened. In 2009, top economist and Nobel laureate Paul Krugman wrote that the trade deficit, by definition, requires a corresponding inflow of capital to fund it, which in turn, can further lead to lower interest rates and stimulate the creation of bubbles. "For a while, the inrush of capital created the illusion of wealth in these countries, just as it did for American homeowners: asset prices were rising, currencies were strong, and everything looked fine. But bubbles always burst sooner or later, and yesterday's miracle economies have become today's basket cases, nations whose assets have evaporated but whose debts remain all too real" 33 . The trade deficit also may be affected by changes in relative labor costs, which have made the countries of southern Europe less competitive and increased their trade imbalances. Since 2001, labor costs in Italy are higher than those in Germany by $32 \%{ }^{34}$. In the last decade, also labor costs in Greece have increased dramatically in relation to the same costs in Germany. Indeed, the case of Greece and Italy was not alone. On the contrary, most of the EU countries registered an increase in labor costs much more than in Germany. Those countries who are allowed "to grow wages faster than productivity" lost their competitiveness. On the contrary, Germany has had almost the same cost of its workforce, and this questionable factor in the trade imbalances was crucial for low unemployment rate in this country.

Further, Eurozone countries with sustained trade surpluses (i.e., Germany) do not see their currency appreciate relative to the other Eurozone nations due to a common currency, keeping their exports artificially cheap. Germany's trade surplus within the Eurozone declined in 2011 as its trading partners were less able to find financing necessary to fund their trade deficits, but Germany's trade surplus outside the Eurozone increased, as the euro depreciated against the dollar and other currencies.

\subsection{Practices of rescuing troubled European banks and financial funds by their Governments}

A number of economists have dismissed the popular opinion that the debt crisis was caused by excessive social welfare spending. According to their analysis, increased debt levels were mostly due to the large bailout packages provided to the financial sector during the global financial crisis (20072009) and the global economic slowdown thereafter. The average fiscal deficit in the euro area in 2007 was only $0.6 \%$ before it grew to $7 \%$ during the financial crisis. In the same period, the average government debt rose from $66 \%$ to $84 \%$ of GDP. The authors also stressed that fiscal deficits in the euro area were stable or even shrinking since the early 1990s. American economist Paul Krugman ponted out that Greece is the only country where fiscal irresponsibility is the main cause of the crisis. British

\footnotetext{
${ }^{32}$ Story, Louise;Landon Thomas Jr., Nelson D. Schwartz (14 February 2010) “Wall St. Helped Mask

Debrt Fueling Europe Crisis “ New York Times (New York) 29 September 2011

http://www.nytimes.com/2010/02/14/business/global/14debt.html?pagewanted=all\&_r=1\&

${ }^{33}$ Paul Krugman "Revenge of the Glut", http://www.nytimes.com/2009/03/02/opinion/02krugman.html, 2011

${ }^{34}$ Antonio Fatas "Competitiveness and the European Crisis"(May 22, 2012)
} 
economic historian Robert Skidelsky adds that excessive lending by the banks, rather than increased public spending and budget deficit, caused the sovereign debt crisis. Namely, he stated that the significant increase in government debt of certain European countries is the consequence, not the cause of the economic crisis.

\subsection{Structural problems of the Eurozone}

There is a structural contradiction within the euro system. Namely that there is a monetary union (common currency) without a fiscal union (e.g., common taxation, pension, and treasury functions). In the Eurozone system, the countries are required to follow a similar fiscal path, but they do not have common treasury to enforce it. That is, countries with the same monetary system have freedom in fiscal policies in taxation and expenditure. So, even though there are some agreements on monetary policy and through the European Central Bank, countries may not be willing or able to follow it. This feature brought fiscal free riding of peripheral economies, especially represented by Greece, as it is hard to control and regulate national financial institutions. Furthermore, there is also a problem that the Eurozone system has a difficult structure for quick response. Eurozone, having 17 nations as its members, require unanimous agreement for a decision making process. This would lead to failure in complete prevention of contagion of other areas, as it would be hard for the Eurozone to respond quickly to the problem.

\subsection{Monetary policy inflexibility of the Eurozone}

Membership in the Eurozone established a single monetary policy, preventing individual member states to act independently. In particular the memebering countries cannot issue Euros in order to pay creditors and eliminate their risk of default. Since they share the same currency as their trading partners, they cannot devalue their currency to make their exports cheaper, which in principle would lead to an improved balance of trade, increased GDP and higher tax revenues in nominal terms. In the reverse direction moreover, assets held in a currency which has devalued, suffer losses on the part of those who hold them. For example, by the end of 2011, given the devaluation of the euro against the pound by $25 \%$, and $5 \%$ increase of inflation, eurozone investors in pounds, which claims were locked in a fixed exchange rate (Euro / pound), lost approximately $30 \%$ in the repayment value of their claims .

\subsection{Loss of confidence in the Eurozone mechanisms}

Prior to development of the last financial crisis it was assumed by both regulators and banks that sovereign debt from the eurozone was safe. Banks had substantial holdings of bonds from weaker European economies, which offered a small premium and seemingly were equally sound. As the crisis developed it became obvious that those countries' bonds offered substantially more risk. Contributing to lack of information about the risk of European sovereign debt was conflict of interest by banks that were earning substantial sums underwriting the bonds. The loss of confidence is marked by rising sovereign CDS prices and interest rates, indicating market expectations about countries' creditworthiness. (Figure 3)

Figure 3 Long term interest rates in Eurozone (2009-2014)

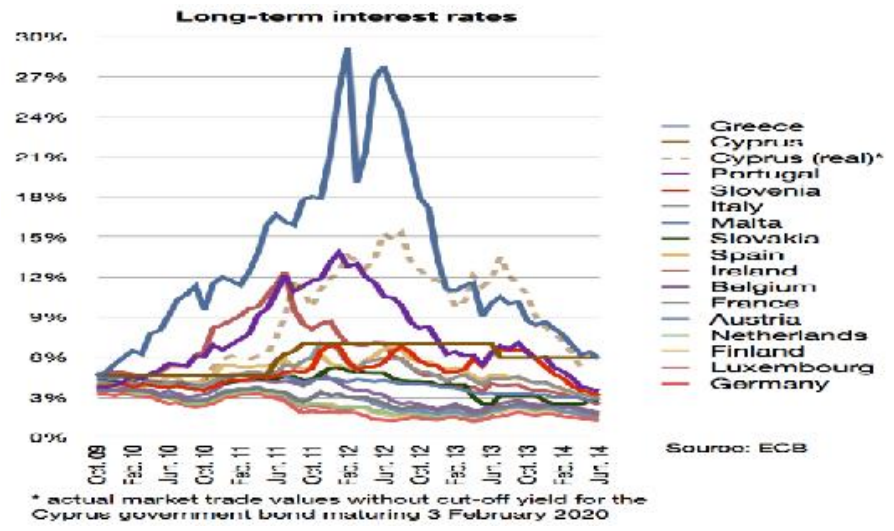




\section{Source: European Central Bank}

In addition, investors had doubts about the ability of policy makers to contain crisis quickly and eficciently. Since countries that use the euro as their currency have fewer monetary policy choices (e.g., they cannot print money in their own currencies to pay debt holders), certain solutions required multinational cooperation. Further, the European Central Bank has an inflation control mandate but not an employment mandate, as opposed to the U.S. Federal Reserve, which has a dual mandate.

According to numerous reports, a further decline of euro in June 2012, made rich investors to move their finances out of Eurozone, or within the Eurozone movement of funds from South to North. Namely, between June 2011 and June 2012, only Spain and Italy lost 286 billion euros and 235 billion euros respectivly. In two years (starting from the end of 2010) the Mediterranean countries have lost assets which represent the value of $10 \%$ of their $\mathrm{GDP}^{35}$.

Bad picture of the economic situation of certain countries from the Eurozone was further worsened by annoucement by the credit rating agencies regarding the reduced credit ratings in several EU countries.Namely, on the $5^{\text {th }}$ of December 2011, Standard\&Poor's placed its long-term sovereign ratings on 15 members of the eurozone on "CreditWatch" with negative implications. S\&P wrote this was due to "systemic stresses from five interrelated factors: 1) Tightening credit conditions across the eurozone; 2) Markedly higher risk premiums on a growing number of eurozone sovereigns including some that are currently rated 'AAA'; 3) Continuing disagreements among European policy makers on how to tackle the immediate market confidence crisis and, longer term, how to ensure greater economic, financial, and fiscal convergence among eurozone members; 4) High levels of government and household indebtedness across a large area of the eurozone; and 5) The rising risk of economic recession in the Eurozone ${ }^{36}$.

\section{Conclusions}

In a nutshell, the European sovereign debt crisis is the result of many separate but interrelated plots, which can be merged in the three main ones: crushing levels of government debt in some countries, problems in the banking sector and the slow growth in Europe. All of these problems which were general ussue in the Eurozone countries were additionaly "spiced" by certain national problems in each of the affected countries. Tying them up in a neat bow is the fact that the euro-area countries are yoked together by a common currency, but they have little else in common economically or culturally. Although the European Central Bank has put stricted rules to prevent fiscal problems, of their members it seemed that no one pay attention on fulfilling the criterias, ignoring internationally agreed standards.

This allowed the Governments to mask their deficit and debt levels through a combination of techniques, including inconsistent accounting, off-balance-sheet transactions, as well as the use of complex currency and credit derivatives. All this created the loss of confidence in the efficiency of European monetary Union mechanisms and the Eurozone countries' creditworthiness.

\section{References}

1. Sheyla Sterner "What caused Europe's debt crisis, anyway?" http://ca.finance.yahoo.com/news/caused-europes-debt-crisis-anyway-070127716.html

2. Lewis, Michael (2011). "Boomerang - Travels in the New Third World". Norton. ISBN 9780-393-08181-7

3. NY Times "It's all connected: Spectator's guide to the World crises", http://www.nytimes.com

\footnotetext{
${ }^{35}$ Landon Thomas - NYT-Worried Banks Resist Fiscal Union-June 17, 2012,

http://www.nytimes.com/2012/06/18/business

36"S\&P-Standard \& Poor's Puts Ratings On Eurozone Sovereigns On CreditWatch With Negative Implications-5 December 2011". 14.05.2012, http://www.standardandpoors.com/ratings/articles/en
} 
4. The Economist "The euro deal -No big bazooka"-, 29.10.2011, http://www.economist.com/node/21534851

5. Story, Louise;Landon Thomas Jr., Nelson D. Schwartz (14 February 2010) “Wall St. Helped Mask Debrt Fueling Europe Crisis “ New York Times (New York) 29 September 2011 http://www.nytimes.com/2010/02/14/business/global/14debt.html?pagewanted=all\&_r=1\&

6. Paul "Revenge of the Glut", http://www.nytimes.com/2009/03/02/opinion/02krugman.html, 2011

7. Antonio Fatas "Competitiveness and the European Crisis"(May 22, 2012)

8. Landon Thomas - NYT-Worried Banks Resist Fiscal Union-June 17, 2012, http://www.nytimes.com/2012/06/18/business

9. "S\&P-Standard \& Poor's Puts Ratings On Eurozone Sovereigns On CreditWatch With Negative Implications-5 December 2011". 14.05.2012, http://www.standardandpoors.com/ratings/articles/en 